\title{
The aquatic leaf beetle Macroplea mutica (Coleoptera: Chrysomelidae) in Europe: Population structure, postglacial colonization and the signature of passive dispersal
}

\author{
Michael MENDE ${ }^{1 *}$, Olof BISTRÖM ${ }^{2}$, Edda MEICHSSNER ${ }^{1}$ and GregOr KÖLSCH ${ }^{1 * *}$ \\ ${ }^{1}$ Molecular Evolutionary Biology, Zoological Institute, University of Hamburg, Martin-Luther-King-Platz 3, \\ 20146 Hamburg, Germany \\ ${ }^{2}$ Zoological Museum, PB 17, 00014 University of Helsinki, Finland
}

Key words. Phylogeography, postglacial colonization, population genetics, amplified fragment length polymorphism, AFLP, Chrysomelidae, Donaciinae, Macroplea

\begin{abstract}
The pattern of postglacial re-colonization of Europe and the present population structure are known for various plant and animal species. The reed beetle Macroplea mutica (Fabricius, 1792) has characteristics that should influence both aspects in a peculiar way and therefore complement the currently known scenarios: It is fully aquatic but cannot swim or fly. Samples from 25 European populations of M. mutica and five specimens from China were investigated using amplified fragment length polymorphism (AFLP, 251 loci). Assessment of error rates associated with this method showed that the data set contains a strong population genetic signal. As hypothesized pronounced population differentiation and signs of inbreeding were found. Italian populations are clearly differentiated from northern populations (and from each other), which underlines the role of the Alps as a major barrier. Specimens from Lake Balaton (Hungary) show some affiliation with the populations in the Baltic Sea, which are all relatively similar. Populations from the eastern part of Northern Germany are similar to the Baltic populations, while those from the western part are allied to the British populations. The hypothesis is that the recolonization of Europe was from both the Southeast and a western refugium in the area of present-day southern England or Ireland, which resulted in a suture zone in Northern Germany. The effect of passive dispersal by drift attached to host plant material (especially in the Baltic Sea) and by zoochory (migrating waterfowl) is discussed.
\end{abstract}

\section{INTRODUCTION}

The present distribution of organisms in Europe was, in evolutionary terms, established relatively recently. The principal climatic factor that has recurrently modified the biota are fluctuations in temperature (Comes \& Kadereit, 1998; Hewitt, 2000; Jansson \& Dynesius, 2002). The last ice age in Europe was around 20,000 years ago. Ice sheets and permafrost extended south to approximately $52^{\circ}$ and $47^{\circ}$ North, respectively (Hewitt, 2004). As the ice retreated, organisms recolonized Central and Northern Europe from southern refugia. The scenarios of recolonization derived for various plants and animals differ in respect of the location of the refugia and the dispersal routes (Taberlet et al., 1998; Hewitt, 1999). Among the model organisms, for which the patterns were initially established, is the widespread grasshopper Chorthippus parallelus (Cooper et al., 1995). Studies of other insects followed, with a focus on Lepidoptera (e.g., Schmitt \& Seitz, 2001; Habel et al., 2005; Schmitt et al., 2005, 2006; Timmermans et al., 2005; Besold et al., 2008; MachlourM'Rabet et al., 2008). Other publications dealt with regional aspects and/or habitat specialists (Halliday et al., 1983; Monaghan et al., 2001; Bereczki et al., 2005; Haubrich \& Schmitt, 2007; Margraf et al., 2007; Schmitt \&
Haubrich, 2008; Previšić et al., 2009). In addition to the pattern of postglacial recolonization, they added classical population genetic issues (gene flow, population connectivity, and inbreeding) to the spectrum of problems addressed. It was established how isolation, due to manmade habitat fragmentation or a naturally disjunct distribution, has a severe effect on the population structure. Isolation is a relative phenomenon that has to take into account the mobility of the organism in question. This is obvious when considering typical aquatic insects like dytiscid beetles and aquatic Hemiptera. As a general rule they fly between habitats in a patchy environment (Bilton et al., 2001).

In contrast, the specific feature of our study species, Macroplea mutica (Fabricius, 1792), which is one of the only four fully aquatic leaf beetles (genus Macroplea Samouelle, 1819; Chrysomelidae: Donaciinae) (Wesenberg-Lund, 1943; Askevold, 1990), is its immobility: locomotion under water is restricted to walking on the substrate and vegetation. Out of water, they are hardly able to walk on their thin and weak legs. They were never observed flying nor can flight be induced by taking them out of the water under various conditions of light, darkness and warmth. Mohr (1985) states that this beetle is fully winged and able to fly but does not provide any fur-

\footnotetext{
* Present address: Museum of Zoology, Senckenberg Natural History Collections Dresden, Königsbrücker Landstraße 159,01109 Dresden, Germany

** Corresponding author; e-mail: gregor.koelsch@uni-hamburg.de
} 
TABLE 1. The abbreviation (code), sample size (n), location, habitat type and names of the collectors of the samples included in this study. Coastal lakes and marine habitats are brackish and inland lakes freshwater habitats.

\begin{tabular}{|c|c|c|c|c|}
\hline Code & $\mathrm{n}$ & Location & Habitat type & Collectors \\
\hline \multicolumn{5}{|c|}{ Macroplea mutica: } \\
\hline$\overline{\text { WAL }}$ & 20 & Great Britain, Wales & coastal lake & G. Kölsch, E. Meichßner \\
\hline EYO & 3 & Great Britain, England, East Yorkshire & coastal lake & G. Kölsch, E. Meichßner \\
\hline CAM & 15 & Great Britain, England, Cambridgeshire & inland lake & G. Kölsch, E. Meichßner \\
\hline ESU & 15 & Great Britain, England, East Sussex & coastal lake & G. Kölsch, E. Meichßner \\
\hline NFL & 13 & Germany, Schleswig-Holstein, Northern Friesland & coastal lake & G. Kölsch, R. Suikat \\
\hline PLW & 15 & Germany, Schleswig-Holstein, western Plön Lakes & inland lake & G. Kölsch, R. Suikat \\
\hline PLO & 15 & Germany, Schleswig-Holstein, eastern Plön Lakes & inland lake & G. Kölsch, R. Suikat \\
\hline BEL & 3 & Germany, Schleswig-Holstein, Lake Selent, Bellin & inland lake & G. Kölsch \\
\hline SEE & 11 & Germany, Schleswig-Holstein, Lake Selent, Seekrug & inland lake & G. Kölsch \\
\hline ORT & 16 & Germany, Schleswig-Holstein, Fehmarn, Orth & marine & G. Kölsch \\
\hline LEM & 17 & Germany, Schleswig-Holstein, Fehmarn, Lemkenhafen & marine & G. Kölsch, M. Mende \\
\hline RUG & 15 & Germany, Mecklenburg-Vorpommern, Rügen & marine & G. Kölsch, E. Meichßner \\
\hline HEL & 11 & Denmark, Funen, Helnæs & marine & G. Kölsch \\
\hline OBJ & 15 & Denmark, Zealand, Øbjergstrand & marine & G. Kölsch, R. Suikat \\
\hline UTO & 5 & Sweden, Södermanland, Utö & marine & H.-E. Wanntorp \\
\hline VAX & 6 & Sweden, Uppland, Vaxholm & marine & H.-E. Wanntorp \\
\hline OST & 15 & Sweden, Västerbotten, Ostnäs bei Umeå & marine & A. Nilsson \\
\hline DRA & 4 & Finland, Varsinais-Suomi, Dragsfjärd & marine & O. Biström \\
\hline KIR & 5 & Finland, Uusimaa, Kirkkonummi & marine & O. Biström \\
\hline VOR & 8 & Estonia, Vormsi & marine & O. Biström \\
\hline SAR & 14 & Italy, Sardinia & coastal lake & G. Kölsch, E. Meichßner \\
\hline LOM & 15 & Italy, Lombardy & inland lake & G. Kölsch, E. Meichßner \\
\hline BOL & 6 & Italy, Latium, Lake Bolsena & inland lake & G. Kölsch, E. Meichßner \\
\hline BRA & 15 & Italy, Latium, Lake Bracciano & inland lake & G. Kölsch, E. Meichßner \\
\hline BAL & 4 & Hungary, Lake Balaton & inland lake & I. Musko \\
\hline $\mathrm{CHI}$ & 5 & PR of China, Heilongjiang, Daqing & inland lake & $\begin{array}{l}\text { G.A. Buckingham, C. Zhiqun, } \\
\text { C.A. Bennett, D. Jianqing }\end{array}$ \\
\hline \multicolumn{5}{|c|}{ Macroplea appendiculata: } \\
\hline AP_SEE & 17 & Germany, Schleswig-Holstein, Lake Selent, Seekrug & inland lake & G. Kölsch \\
\hline AP_NFL & 2 & Germany, Schleswig-Holstein, Northern Friesland & coastal lake & G. Kölsch, R. Suikat \\
\hline AP_OST & 1 & Sweden, Västerbotten, Ostnäs near Umeå & marine & A. Nilsson \\
\hline
\end{tabular}

ther information. Mann \& Crowson (1983) classify the hindwing venation of Macroplea as "most reduced known in Donaciinae", which supports a reduced ability to fly. However, this striking immobility in and out of water did not prevent the genus from colonising Northern and Central Europe (as well as other parts of the Palearctic; Borowiec, 1984; Kölsch et al., 2006) after the last ice age, which must have been by passive dispersal (see Discussion).

The immobility on the one hand and passive dispersal on the other hand should have affected the present population genetic structure. The present study describes the degree of genetic differentiation between populations and evaluates their genetic impoverishment due to inbreeding. The pattern derived is interpreted in terms of postglacial recolonization and present dispersal. This approach explicitly spans both population genetics and phylogeography.

For the analysis the method of amplified fragment length polymorphism (AFLP; Vos et al., 1995) was chosen because of its proven applicability for insect population genetic studies (McMichael \& Prowell, 1999; Parsons \& Shaw, 2001; Tan et al., 2001; Miller et al., 2002; Salvato et al., 2002; van der Wurff et al., 2003; Kazachkova et al., 2004) and practical advantages (Vos et al., 1995; Mueller \& Wolfenbarger, 1999).

\section{MATERIAL AND METHODS}

\section{Sampling}

The animals originated from 25 European populations and three locations in North-east China (Table 1; Fig. 1). Due to their relative proximity to each other, the latter were treated as one population, resulting in a total of 26 populations. Samples were collected between 2001 and 2007 (China: 1994/95) and stored in $100 \%$ ethanol and/or deep frozen. Only a subset of some adult beetles (if available) from each population was determined morphologically. Beyond that we considered the information on the localities as sufficient evidence that beetles were $M$. mutica: The habitat type delimits $M$. mutica from $M$. appendiculata (Freude et al., 1966; Mohr, 1985). Personal communications from collectors or earlier descriptions (Székessy, 1941; Daccordi \& Ruffo, 1978) suggest that only M. mutica is present at the specific locations. Four morphologically identified individuals of the sister species M. appendiculata (Panzer, 


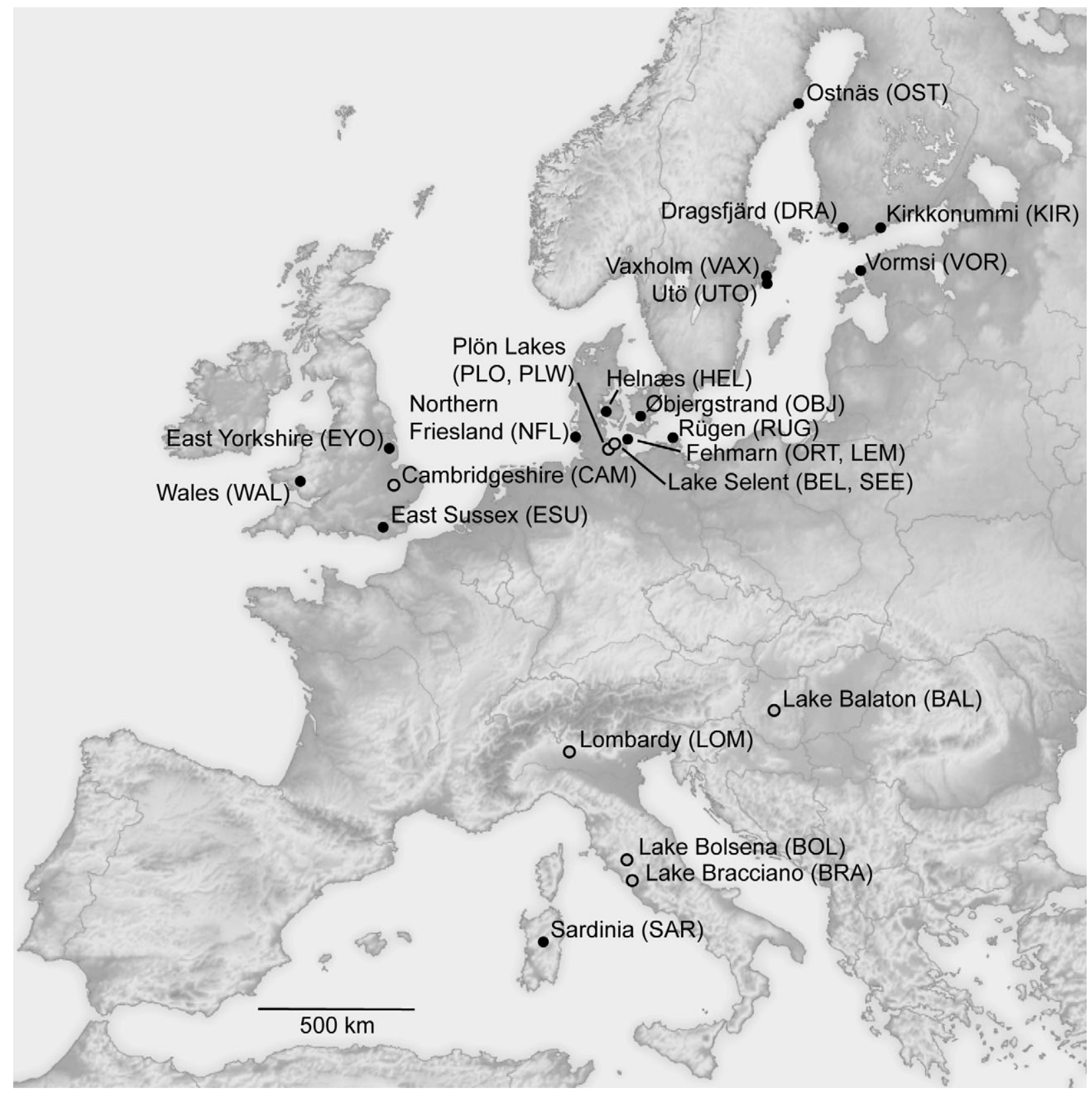

Fig. 1. Geographical distribution of the populations sampled. Black circles = coastal lake/marine habitat; grey circles with black lining $=$ inland lake.

1794) were included for comparison (outgroup and reference for detecting inadvertently included specimens from that species, especially larvae).

\section{Laboratory procedures}

Genomic DNA was extracted following the protocol of Sokolov (2000), but without phenol-chloroform-extraction (Sauer \& Hausdorf, 2009). A lateroventral slice of the abdomen of larvae and pupae was used and of adult beetles it was two or three legs cut in pieces smaller than $1 \mathrm{~mm}$. The DNA concentration was measured with an Ultrospec 2100 pro spectrophotometer (Amersham) and adjusted by dilution with buffer to $100 \mathrm{ng}$ in the 23 $\mu 1$ used for the restriction. This volume was mixed with $17 \mu \mathrm{l}$ of the following enzyme solution: $12.25 \mu \mathrm{l} \mathrm{H}_{2} \mathrm{O}, 4 \mu \mathrm{l} 10 \times$ "Orange" buffer (Fermentas), $0.25 \mu \mathrm{l}$ EcoRI $(20 \mathrm{U} / \mu \mathrm{l}), 0.5 \mu \mathrm{l}$ PstI $(10 \mathrm{U} / \mu \mathrm{l})$. The restriction lasted $1.5 \mathrm{~h}$ at $37^{\circ} \mathrm{C}$. Then the following reagents were added to ligate the adapters: $1.8 \mu 1 \mathrm{H}_{2} \mathrm{O}$, $0.5 \mu 110 \times$ "Orange" buffer, $1 \mu 1$ ATP $(10 \mathrm{mM}), 1 \mu 1$ of each of the two adapters $(5 \mu \mathrm{M}), 0.2 \mu 1 \mathrm{~T} 4 \mathrm{DNA}$ ligase $(5 \mathrm{Weiss} U / \mu \mathrm{l})$. The ligation lasted three hours at $37^{\circ} \mathrm{C}$, after which the restriction enzymes were inactivated $\left(20 \mathrm{~min}\right.$ at $\left.65^{\circ} \mathrm{C}\right)$ to avoid star activity. The two adapters were produced by heating to $98^{\circ} \mathrm{C}$ and slowly cooling solutions of two partly overlapping, complementary oligonucleotides: for EcoRI 5'-CTCGTA GACTGCGTACC-3' and 5'-AATTGGTACGCAGTCTAC-3', for PstI 5'-GACGTGACGGCCGTCATGCA-3' and 5'TGACGGCCGTCACG-3'.

A screening of twelve primer combinations revealed that the combination EcoRI-TG and PstI-TC yielded a clear banding pattern (terminal capital letters in the primer name denote the selective nucleotides added to the core primer sequence that is complementary to one strand of the adapter): EcoRI-TG: 5'GACTGCGTACCAATTCTG-3' and PstI-TC: GACGGCCGT CATGCATC-3'. The EcoRI-primer was labelled with an infrared dye $(700 \mathrm{~nm})$ for fragment detection. Two consecutive 
PCR reactions were run. The primers in the pre-amplification lacked the last selective base at the 3'-end. The volumes added were: $9.8 \mu 1 \mathrm{H}_{2} \mathrm{O}, 2 \mu 1 \mathrm{10} \times$ PCR buffer, $0.8 \mu 1 \mathrm{MgCl}_{2}(50 \mathrm{mM})$, $1.6 \mu \mathrm{l}$ dNTPs $(2.5 \mathrm{mM}$ each $), 0.3 \mu \mathrm{l}$ of each primer $(5 \mu \mathrm{M}$ each), $0.2 \mu 1$ Taq DNA-polymerase $(5 \mathrm{U} / \mu \mathrm{l}), 5 \mu \mathrm{l}$ of the adapter ligation product. The $20 \mathrm{PCR}$ cycles each consisted of $30 \mathrm{~s}$ denaturation at $94^{\circ} \mathrm{C}, 1 \mathrm{~min}$ annealing at $56^{\circ} \mathrm{C}$ and $1 \mathrm{~min}$ elongation at $72^{\circ} \mathrm{C}$. The product of the pre-amplification was diluted $1: 10$ and $10 \mu \mathrm{l}$ were used in the selective amplification together with buffer, $\mathrm{MgCl}_{2}$, dNTPs and polymerase as before, 3 $\mu 1 \mathrm{H}_{2} \mathrm{O}$ and $1 \mu \mathrm{l}$ of each primer with two selective nucleotides (1.5 $\mu \mathrm{M}$ each). This second PCR was run in the touch-down mode: $30 \mathrm{~s}$ denaturation, $30 \mathrm{~s}$ annealing and 2 min elongation (first twelve cycles) or $1 \mathrm{~min} 30 \mathrm{~s}$ elongation (cycle 13-35). The annealing temperature started at $65^{\circ} \mathrm{C}$, was reduced by $0.7^{\circ} \mathrm{C}$ per cycle during the following eleven cycles and then remained at $56^{\circ} \mathrm{C}$. The products were stored at $4{ }^{\circ} \mathrm{C}$ until electrophoresis on a Licor $4200 \mathrm{~L}$ automated sequencer using a $25 \mathrm{~cm}$ long $6 \%$ denaturing acrylamide gel. The samples were arranged on a gel in semi-randomized manner: populations were split to run on different gels and individuals with shared origin were not positioned next to each other.

\section{Data analysis}

For the analysis of the gel images the software GelCompar II v. 5.0 Suite Demo (Applied Maths NV, Belgium) was used. Only fragments in the size range of $45-540$ bases were evaluated. Samples with very weak banding patterns were re-run. Bands with an intensity of at least $2 \%$ of the maximum intensity in a lane were scored as present. To enable the combined analysis of different gels, the software provides two ways of optimizing the identification of corresponding bands in the samples (bandmatching), also across gels: "optimization" and "tolerance" (see software manual). Both values were adjusted so that the "gel-duplicates" of the standard individuals (see below) were most closely related to each other in the phylogenetic tree simultaneously provided by the software (neighbor joining with distances calculated according to Dice 1945; a tree with optimization $=3.9 \%$ and tolerance $=0.3 \%$ forms the basis of Fig. 1). The internal band-matching of the software is done pair wise, i.e. only two banding patterns are compared at a time to identify corresponding bands. However, a global band-matching, which uses all samples simultaneously, is used for the export of the data as a 0,1 -matrix. Since there is no way of adjusting the settings for the global band-matching while monitoring the effect of manipulations, this global band-matching and hence the export of the binary matrix was also run with the settings optimized for the pair wise band-matching.

The following measures were taken in order to quantify the sources of error. In a pilot study to test the general reliability of banding patterns, two independent analyses for three individuals, each starting with the DNA-extraction, were conducted ("extraction-duplicates", quantifying error source A). Also, starting from a common adapter ligation, samples of these three animals were replicated four times in a pre-amplification and a selective amplification (error source B). The resulting banding patterns were analysed manually, which proved more reliable than automatic scoring but is unrealistic for an entire data set. The three standard individuals from geographically distant populations were included on every gel in the same position ("gel-duplicates", error source C). For each sample, duplicate selective amplifications were run and the products were loaded adjacent to each other on a gel ("PCR-duplicates", error source D) in order to identify differences in the results that could be related to altered overall intensities of the patterns.
Most of the population genetic analyses were conducted only on the 26 populations of $M$. mutica. A "simple matching coefficient" (Sokal \& Michener, 1958; Kosman \& Leonard, 2005; Bonin et al., 2007), calculated from the binary matrix, was used for an analysis of molecular variance (AMOVA) using Arlequin v. 3.0 (Excoffier et al., 2005). Three levels were considered: level one was the variance between the PCR- and gel-duplicates (= within individual, equivalent to an error term), level 2 the variance between individuals within a population, and level three the variance between populations. The significance was tested based on 1000 permutations. Only one of the two PCRduplicates of a sample was included. The software Hickory v. 1.0.4 (Holsinger \& Lewis, 2003) was used to calculate f and $\theta^{\mathrm{B}}$, the Bayesian analogues to $F_{\text {IS }}$ and $F_{\text {ST. Probabilities of models, }}$ assuming that one of these values is zero, were compared to that of a full model without assumption. AFLP-SURV (Vekemans, 2002) was used to estimate allele frequencies (assuming HardyWeinberg-equilibrium) and to calculate the total $\mathrm{F}_{\mathrm{ST}}$, pair wise $\mathrm{F}_{\mathrm{ST}}$ for populations (100 permutations) and genetic distances after Nei (1987) between populations (100 bootstrap replicates). The genetic distances were used to produce a neighbor joining phylogram and the consensus tree from the bootstrap replicates in PHYLIP v. 3.6 (Felsenstein, 2005).

The population structure was assessed by using the software BAPS v.5.1 (Corander et al., 2003, 2004). The maximum number of populations, $\mathrm{K}_{\max }$, was set to $5,10,20$ or 30 , with five replicate runs each. The admixture analysis was conducted for both the geographically defined populations and the clusters detected by the software (100 iterations, 100 reference animals, 10 iterations per reference individual). The spatial pattern of genetic diversity ("isolation by distance") was analysed in SPAGeDi v.1.2 (Hardy \& Vekemans, 2002). Geographic distances between sampling locations were calculated using the geofunc.xla add-in for Microsoft Excel (http://www.afsc. noaa.gov/nmml/software/excelgeo.php). The kinship coefficient implemented in SPAGeDi was used as measure of genetic similarity. The significance was tested based on 1000 permutations.

\section{RESULTS}

\section{Error rates and reproducibility}

The pilot study revealed that on average $2.6 \%$ of the bands (size 45-540 bases) of extraction-duplicates (error source A, see above) are artificial, which is equivalent to $1.3 \%$ of the genetic distance (Dice, 1945). The replicated PCRs (error source B) revealed that the variance introduced during the PCR steps was below $0.01 \%$ as long as the banding patterns are of comparable intensity. Weak profiles inflated this rate, and consequently samples exhibiting very weak patterns were repeated (usually from selective PCR onwards). The genetic distance between the PCR-duplicates (error source D) of all individuals was $6.6 \%$ (standard deviation SD: $3.4 \%$ ). In all cases they were positioned adjacent to each other in the phylogram, for a reasonable range of the bandmatching tolerance settings. The genetic distance between the gelduplicates of the three standard individuals (error source C) was $19.0 \%$ (SD: $7.9 \%$ ). This distance was due to differences between the gel runs, which could not be fully corrected for by internal standards. The differences between duplicates (error sources $\mathrm{C}$ and $\mathrm{D}$ together) accounted for $39.46 \%$ of the total variation (AMOVA; Table 2). Within a population, the distance between individuals was on average $31.5 \%$ (SD: $7.8 \%$ ). This means 
TABLE 2. Analysis of molecular variance (AMOVA).

\begin{tabular}{lcccc}
\hline Source of variation & df & SS & Proportion of variation & p-value \\
\hline Between populations & 25 & 21.193 & $14.18 \%$ & $\leq 0.001$ \\
Between individuals within a population & 260 & 59.090 & $46.36 \%$ & $\leq 0.001$ \\
Between PCR- and gel-duplicates within an individual & 339 & 22.193 & $39.46 \%$ & $\leq 0.001$ \\
\hline
\end{tabular}

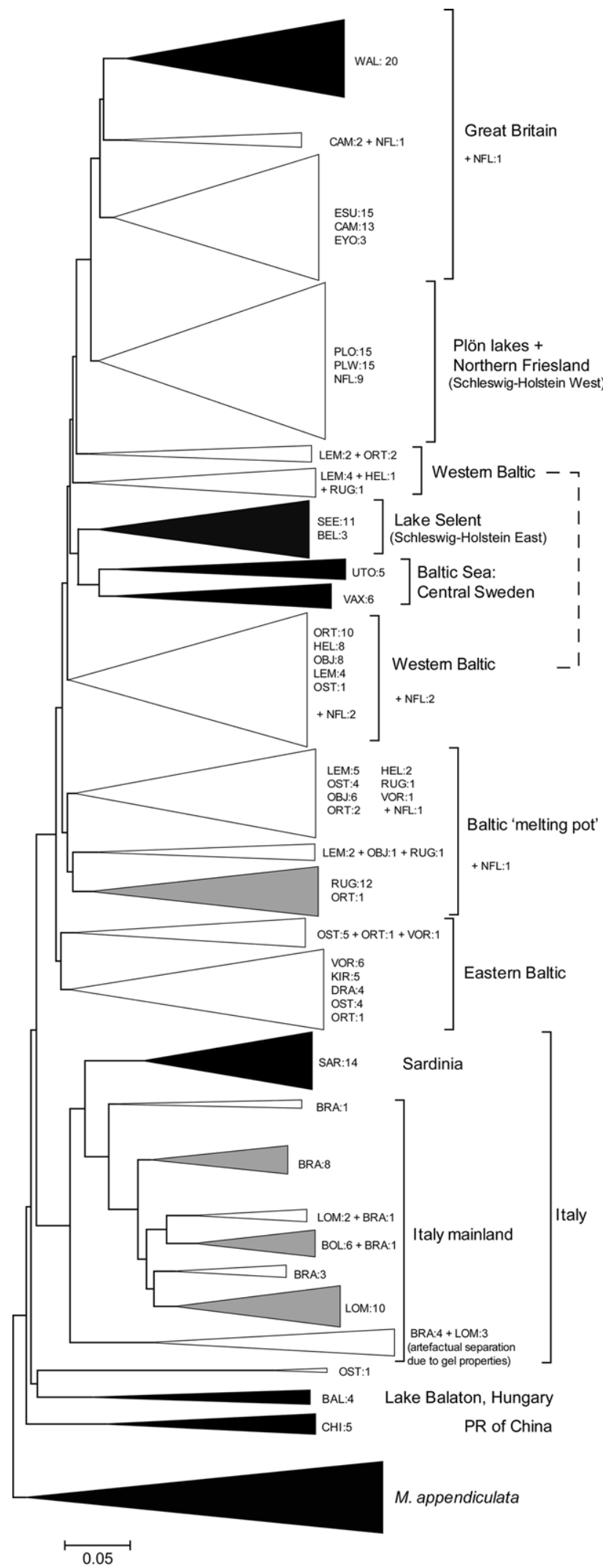

that inter-individual distances were considerably greater than the error that resulted from the differences between gels per se, adding another $46.36 \%$ to the total genetic variation. Genetic distances between populations were ca. $32-36 \%$ at shorter geographic distance and up to approximately $45 \%$ between geographically distant populations. Interspecific comparisons yielded a $50-55 \%$ genetic distance. Since all these values are higher than the intrapopulation distances and error rates, the between populations comparison (i.e., the usable signal), like the other levels, contributes significantly to the genetic variance in the data set $(14.18 \%$; all $\mathrm{p} \leq 0.001$; Table 2$)$.

\section{Population genetics and phylogeography}

Using the fully established method, 682 profiles of 306 individuals on 13 gels could be analysed. On average, 11.0 individuals per population were included (SD: 5.3 ind.). The binary matrix exported from GelCompar contained scorings for 251 loci. The data set used in further population genetic analyses consisted of 306 profiles: one of the two PCR-duplicates of the 286 specimens of $M$. mutica (20 specimens of $M$. appendiculata were excluded: four had originally been included as an outgroup, another 16 were detected among the samples during the analyses), plus 20 of the individual gelduplicates that were distant from the counterpart in the phylogram.

Certain features of the neighbor joining phylogram are visualised in a simplified tree (Fig. 2): Samples from China and Hungary (Lake Balaton) are closest to the root (M. appendiculata). The next split in the tree separates Italian samples from all the rest. Italian populations are remarkably distant from each other. Samples from Sardinia form a monophylum and those from the mainland focal clusters. In the large Northern/Central European cluster, relatedness to southern populations decreases from east to west. Branching off next, but rather weakly differentiated, is the Northern and Eastern Baltic Sea

Fig. 2. Neighbor joining tree of individual samples. In the phylogram produced by GelCompar (see text), major branches were collapsed into triangles using the software MEGA 4.0 (Tamura et al., 2007). Triangle height is proportional to the number of individuals included. Details are given next to the triangles: abbreviated population names (see Table 1) and the number of specimens included. Intensity of shading of the triangles indicates extent of purity of the clusters; white: samples from more than one population are mixed; grey: focal cluster of a population (contains most of its members and/or few individuals from outside); black: monophyletic (i.e., only contains members of a population/species). Square brackets embrace units of common geographic origin (the hatched line connects non-monophyletic clusters). 


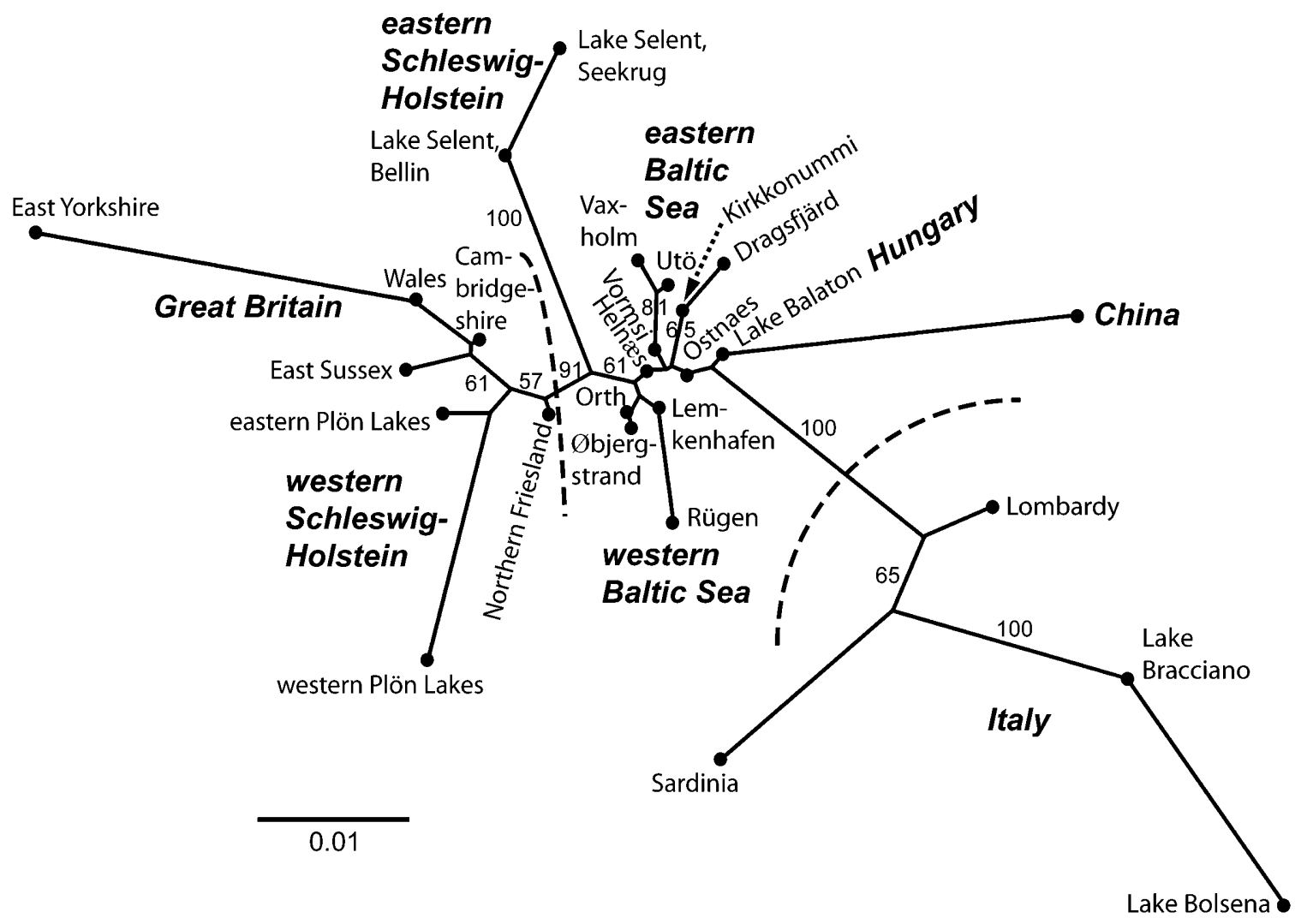

Fig. 3. Neighbor joining tree based on genetic distances (Nei, 1987) between populations. Bootstrap values (based on 100 replicates) above $50 \%$ are given next to the branches. Dashed lines: important geographic barriers/zones of strong genetic differentiation (Alps; suture zone in Schleswig-Holstein, Northern Germany). The names of relevant larger regions are given.

cluster. The Central and Western Baltic Sea is genetically mixed (Baltic "melting pot"), with some separation of populations off the Island of Rügen, along the coast of Central Sweden and in the western part (Germany, Denmark). The Central Swedish populations are positioned as the sister group to animals from Lake Selent in Schleswig-Holstein East (Northern Germany). Separated from this Baltic area are the populations in the western part of Schleswig-Holstein and, as a separate cluster, Great Britain. The former group is not fully monophyletic, because four samples from Nordfriesland (NFL) are scattered among the Baltic and British clusters. Within the British cluster, the sample from Wales forms a monophylum.

In an overall similar picture, the neighbor joining tree based on genetic distances between populations (Fig. 3) illustrates the large distances between the Italian populations. The Baltic populations form a rather compact group at the centre of the phylogram, while branches and inter- nodes become longer towards the west. The bootstrap support for most steps is weak, but the well supported ones $(>75 \%)$ are of particular interest. Two of them separate and split Italy (100\% each), respectively. Another two are associated with the branch leading to Lake Selent $(100 \%)$ and the internode isolating Western SchleswigHolstein along with Great Britain (91\%).

\section{Measures of population differentiation}

The assumption of no differentiation between populations is not tenable (analysis in Hickory, Table 3), because the relevant value of the deviance information criterion (DIC) is highest for the corresponding model $\theta^{\mathrm{B}}$ $=0$. Likewise, the assumption of no inbreeding $(\mathrm{f}=0)$ yields slightly worse model parameters (DIC, $\mathrm{pD}, \bar{D})$ than the full model, under which $\mathrm{f}$ is estimated at 0.99 (= strong indication of inbreeding). The $\theta^{\mathrm{II}}$, an analogue to $\mathrm{F}_{\mathrm{ST}}$ reflecting the degree of current population differentiation, is calculated as 0.135 (SD: 0.004), indicating "mod-

TABLE 3. Model choice criteria calculated in Hickory. Small values favour a given model. The most relevant parameter is the deviance information criterion (DIC): The model with the lowest DIC value (full model) is preferred over assumptions of $\mathrm{f}=0$ (equivalent to "no inbreeding") and $\theta^{\mathrm{B}}=0$ ("no population differentiation"). For further details see Holsinger \& Lewis (2003).

\begin{tabular}{ccccc}
\hline & full model & $\mathrm{f}=0$ & $\theta^{\mathrm{B}}=0$ & $\mathrm{f}$-free model \\
\hline $\bar{D}$ & 18844.3 & 18868.5 & 28716.8 & 19099.6 \\
$\widehat{D}$ & 15680.7 & 15648.2 & 28469.2 & 15465.9 \\
$\mathrm{pD}$ & 3163.6 & 3220.3 & 247.7 & 3633.7 \\
$\mathrm{DIC}$ & 22007.9 & 22088.7 & 28964.5 & 22733.2 \\
\hline
\end{tabular}


a)

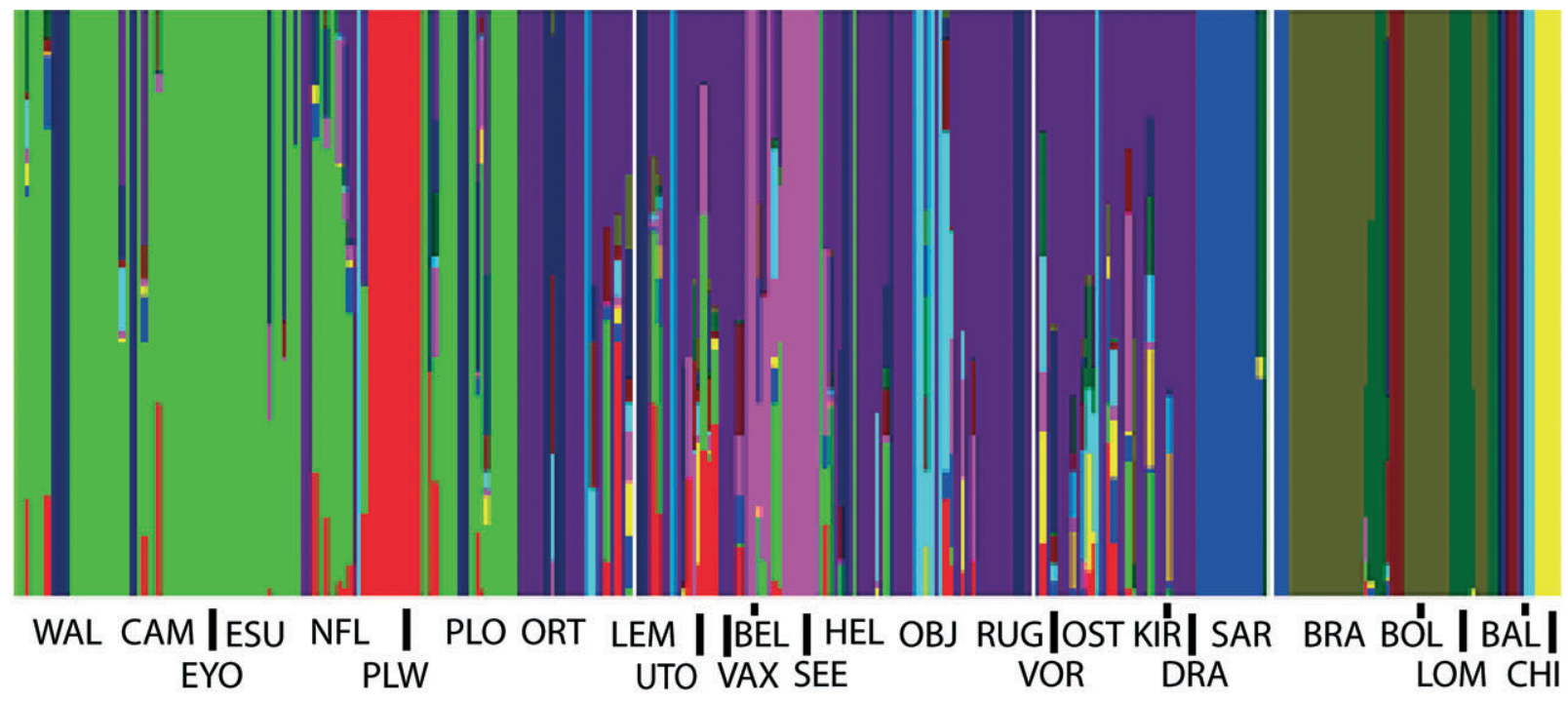

b)

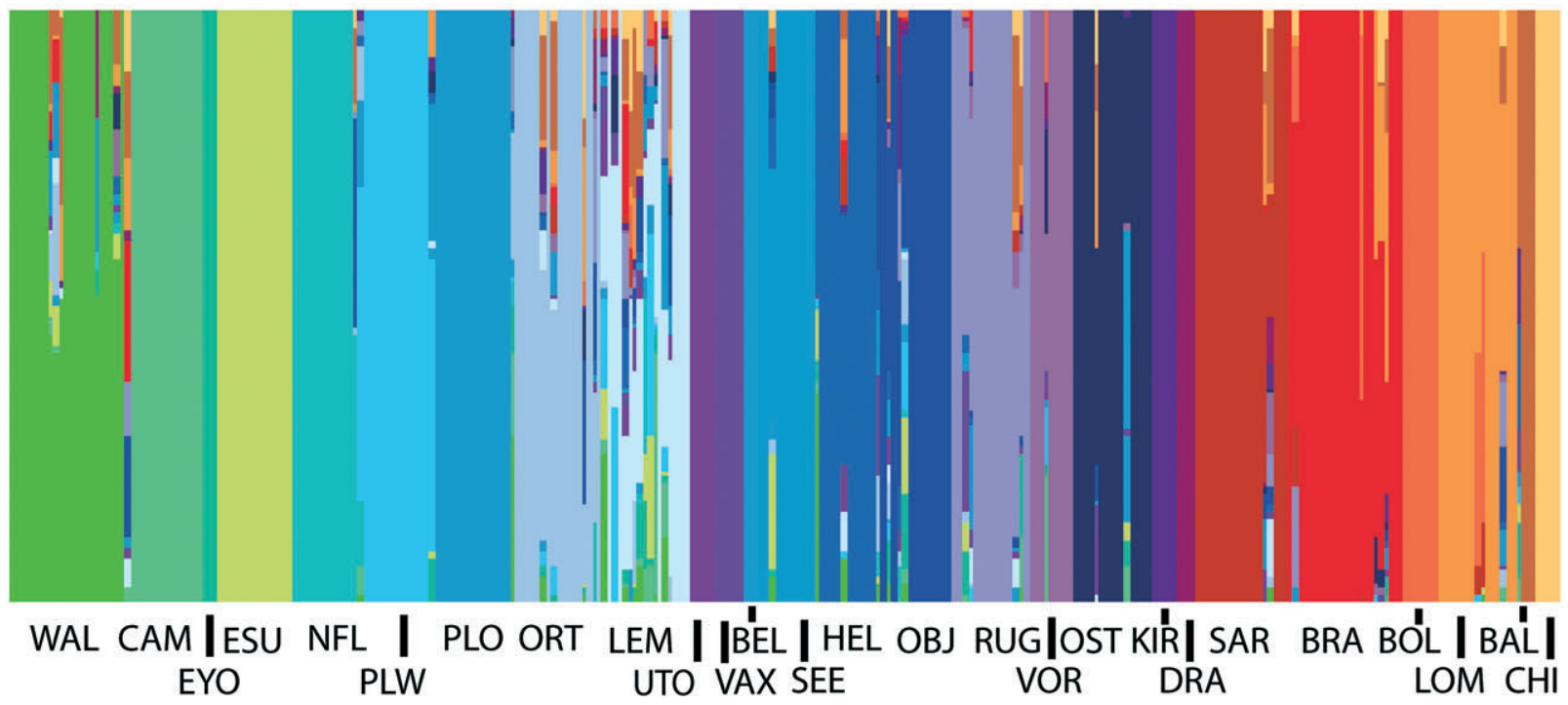

Fig. 4. Admixture analysis conducted in BAPS; (a) based on the 14 clusters (each represented by a different colour) of genetically similar individuals detected by the software; (b) based on the 26 geographically defined populations (sampling locations indicated by the colour). The samples are arranged in the same order in both figures. The three letter code for each population is that cited in Table 1. Individuals are represented by thin columns (adjacent columns of the same colour merge). Columns for genetically admixed individuals consist of more than one colour.

erate" population differentiation (Hartl \& Clark, 2007). This is substantiated by the average pairwise $\mathrm{F}_{\mathrm{ST}}$ calculated using AFLP-SURV (0.084, SD: 0.139).

\section{Population structure and admixture analysis}

The population structure detected by BAPS encompasses $\mathrm{K}=13$ clusters (seven out of ten most probable subdivisions) or $\mathrm{K}=14$ clusters (the remaining three out of ten). However, the estimated probability for $\mathrm{K}=14$ is higher $(93.1 \%$ versus $6.9 \%$ for $\mathrm{K}=13)$. The 14 clusters are (Fig 4a): China; Sardinia (part); three mixed Italian clusters; one cluster consisting of 113 samples from the Baltic (and a few others, including one from Lake Balaton); one Baltic/Balaton-cluster (11 ind.); two clusters of samples from one lake in Schleswig-Holstein; one with 70 samples from Western Schleswig-Holstein and Great Britain; one mixed group (23 ind.); and three separate individuals. Assuming there are 14 populations, $78.8 \%$ of all individuals are assigned to one cluster with $100 \%$ probability. For $12.7 \%$ of all individuals an admixed genome is likely $(\mathrm{p} \leq 0.05)$. If one uses the geographically defined populations (= sampling units; Fig. 4b), it has little effect on these percentages $(83.7 \%$; 8.5\%). Populations in the Baltic Sea show a particularly high percentage of animals with an admixed genome. Animals from Lake Balaton resemble those from the Baltic. Many animals with a mixed genome possess signatures of various origins. There is a significant relationship between genetic and geographic distance as genetic similarity decreases with geographic distance (with the latter on both a linear or logarithmic scale; $\mathrm{p} \leq 0.001$ ). 


\section{DISCUSSION}

\section{Methodology}

A key step in the optimization of the AFLP method for the genus Macroplea was the substitution of the restriction enzyme PstI for MseI, which resulted in much more even distribution of fragment lengths. This reduces one of the two major error sources (Bonin et al., 2007; Meudt \& Clarke, 2007), namely the homoplasy due to fragments of the same size from different loci (which had been likely to occur in the lower size range).

The scoring (absence/presence of bands) and the identification of homologous bands on different gels were optimized by using the software GelCompar. The gelduplicates of standard samples allowed an objective evaluation of the adjustments of the software settings. The efforts we took to monitor the error rate $(10 \%$ of a gel used for gel-duplicates of standard animals) accord with the recommendations of Bonin et al. (2007).

The uncertainties introduced by the difficulties of combining data from different gels are considerable. This contrasts with the generally high reproducibility of the method if one considers only the banding pattern (error rate: 2-5\%; Pompanon et al., 2005; Bonin et al., 2007; Meudt \& Clarke, 2007; this study: error sources A and B). The AMOVA shows that our data set contains a significant population genetic signal in excess of the error rate. This is the relevant conclusion sensu Bonin et al. (2007), who state that the maximum tolerable error rate depends on the specific aim and circumstances of a study.

Another type of uncertainty in population genetic analyses depends on the number of specimens collected from each population. One recommendation for dominant markers like AFLP is a sample size of 30 (Krauss, 2000). In practice, 15 individuals per population are commonly used (Nybom, 2004). Our average sample size is slightly smaller (11.0). However, we could take advantage of the effect that a small sample size can be traded off by a larger amount of data, in our case a higher number of AFLP loci (Medina et al., 2006). Species of the genus Macroplea are rare and difficult to find, even in places where they are known to occur, and the number of specimens collected is sometimes limited by circumstances. According to Hollingsworth \& Ennos (2004), at least 250 loci should be investigated if population differentiation is low. This value was reached in the present study, in which a strong population structure was revealed.

There are two consequences of small sample sizes. The first are the low bootstrap values obtained for the phylogram. Highly variable individual fingerprint patterns are typical of the AFLP method (Parsons \& Shaw, 2001; Paupy et al., 2004; Grapputo et al., 2005), and the few loci characteristic for a population can easily be absent in a given bootstrap replicate, resulting in dissolution of a cluster. Second, care must be taken in the interpretation of extreme patterns exhibited by groups of few individuals (like the one from East Yorkshire, EYO, in Fig. 3). In conclusion, bearing in mind all the technical problems, all the analytical procedures indicate a similar population genetic pattern.

\section{Population differentiation and mode of dispersal}

The "moderate" differentiation between populations and the inbreeding indicated by the F-statistic are plausible if one considers the biology of Macroplea. Both aspects are direct consequences of the immobility/ low dispersal ability of the beetles. A comparison with other studies on aquatic insects is difficult because they cover smaller geographic ranges and/or deal with species that actively disperse by flight (see below). It appears that Macroplea has to rely on passive dispersal for the colonization of new habitats. In large water bodies, drift attached to plant material plays an important role. For example, the specimens from Øbjergstrand/DK (OBJ) were washed ashore in their cocoons in winter, some of them still attached to the root of a host plant. The relatively low genetic distances between Baltic populations (Fig. 3) and the high degree of admixture (Fig. 4) support a scenario of frequent gene flow.

The colonization of inland lakes is only possible by vectors, most probably birds. Migratory birds play an important role in the dispersal of aquatic invertebrates by endo- or ectozoochory, even over large distances (Rogers \& Korschgen, 1966; Figuerola \& Green, 2002; Green et al., 2002; Green \& Figuerola, 2005; Green \& Sanchez, 2006). There seems to be ample opportunity for Macroplea to be transferred in this way. The eggs are covered with a rubber-like substance and are laid within plant tissue. The cocoon material is rigid and resists strong chemicals (nitric acid and potassium hydroxide; Böving, 1910). The host plants of M. mutica, namely pondweed Potamogeton (pectinatus) and widgeon grass Ruppia sp., are preferred food of waterfowl (Clausen et al., 2002; Green et al., 2002; Marklund \& Sandsten, 2002). Dispersal by waterfowl is likely and is known to influence the genetic structure of plant populations (Mader et al., 1998; Hangelbroek et al., 2002; King et al., 2002). Thus it is likely that Macroplea (especially cocoons and eggs) are eaten by birds and survive the passage through their digestive tract.

It is likely that the habitats sampled in this study are representative for this species. In the southern refugia this species occurs in large inland lakes (Italy, Balaton), which have been colonised for long periods of time. In contrast, in the north it occurs mainly along the coast. This could reflect the major route of dispersal by migrating waterfowl. Unlike $M$. appendiculata it is thought to be restricted to brackish water (Freude et al., 1966; Mohr, 1985), but this does not conform with our observations (instances of $M$. mutica in freshwater and $M$. appendiculata in brackish water, like the NFL-population included in this study). It is unlikely that $M$. mutica prefers brackish water. Instead, its presence at such sites could reflect the different potential for dispersal of this species and/or differences in host plant preferences.

Even if zoochory made it possible for this species to recolonize Europe after ice ages, it seems to play a smaller role than homogenization by drift in the water. All inland populations are more isolated from one another than the Baltic populations. Most strikingly, Lake Selent 
is only $10 \mathrm{~km}$ away from the Baltic Sea but nevertheless the specimens from these two locations are clearly genetically different. When considering the relative contributions of drift and zoochory one has to keep in mind that in the Baltic both factors are involved. Zoochory may even be more important, since this area is a major wintering site for migratory waterfowl. The birds spend up to several months there, eventually moving to and fro as the weather conditions change (Rüger et al., 1986).

\section{Glacial refugia}

During the last glacial maximum $(23,000-18,000$ years BP; Hewitt, 2004) the ice sheet and permafrost extended south into Northern and Central Europe. The refugia of temperate zone organisms (Iberia, Italy, Balkan/ Caucasus) are only partly covered by the present data set, but this also reflects this species' distribution (c.f. Borowiec, 1984) In Spain, the rare collections of Macroplea seem to be of M. appendiculata (Lays, 2002). In France, our search for Macroplea mutica in suitable habitats did not yield any beetles. The only location for a refugium in south-eastern Europe that we sampled is Lake Balaton, which was situated south of the permafrost during the last ice age (the edge of the permafrost is tentatively taken as the relevant feature determining the distribution of freshwater invertebrates). Macroplea occurs further south-east in the Balkans (Hoinic, 1994), but we were not able to obtain samples from there. The Italian refugium is well represented in our data set.

The strong differentiation between Italian populations is expected because they have existed for a long time there throughout the cold periods (Hewitt, 1996, 2004; Taberlet et al., 1998). Their genetic distance to Lake Balaton is in the same range. This might hint at an only moderate separation of the two refugia, as postulated for other organisms (Taberlet et al., 1998; Schmitt et al., 2005). If the northern end of the Adriatic Sea was a continuous swamp during the last ice age (Gliemeroth, 1995; Picone et al., 2008) then it is possible that M. mutica was continuously distributed throughout South-eastern Europe.

\section{Postglacial re-colonization}

Two patterns of postglacial re-colonization of Europe are proposed. The "leading edge"-expansion, which involved a fast advance of the front and led to a genetically homogeneous population north of the refugia (Hewitt, 2000; but see Excoffier \& Ray, 2008). Alternatively, if the movement north was more gradual, a more pronounced genetic structure can be expected. The correlation between genetic and geographic distance ("isolation by distance"; Slatkin, 1993) observed in M. mutica supports a slow range expansion (which is in line with the minor gene flow over land relative to the situation in the Baltic). Isolation by distance is typical of species with an intermediate dispersal ability (be it active or passive), since sedentary species would show strong population differentiation at all spatial scales (Peterson \& Denno, 1998).
The re-colonization of Europe by animals and plants followed certain patterns, which differ in the relative contribution of the refugial populations and the present position of where the expansion waves met, the contact zones (Hewitt, 1996, 1999, 2004; Taberlet et al., 1998; Schmitt, 2007). The analysis of population structure defines three large regions, which are represented in the data set by Italy, the Baltic and the North Sea Region (Western Schleswig-Holstein and Great Britain). Most of the smaller units can be assigned to one of them. Our data for M. mutica are compatible with a re-colonization from refugia in the east and the isolation of the Italian populations due to the major barrier to dispersal posed by the Alps ("grasshopper paradigm"; Cooper et al., 1995; Hewitt, 2000; Timmermans et al., 2005). This is coupled with the similarity of the samples from China, Lake Balaton and the (eastern) Baltic and increasing genetic distance to the west. To what extent a Far Eastern refugium may have contributed to the re-colonization of Europe, as described by Wahlberg \& Saccheri (2007), could not be assessed using our data set.

The relationship between populations in Italy and Lake Balaton was discussed above. Under a scenario of eastern origin, the zone of strong genetic differentiation in Schleswig-Holstein (Northern Germany) needs explanation. This can be interpreted as merely relatively strong differentiation as compared with the fast colonization of the Baltic Sea that of the mainland occurred more slowly, mainly by zoochory, and then more quickly again to the west over the North Sea, assisted by drift. Under these circumstances, strong genetic structuring can be expected between the inland habitats. Alternatively, a completely different pattern, involving two lines of re-colonization, is possible. In addition to the one from the East, a second front reached Central and Northern Europe from either Iberia ("brown bear paradigm"; Hewitt, 1999) or refugia on the British Isles (there is growing evidence of unglaciated areas on the British Isles during the last ice age: e.g., Sinclair et al., 1998; Stewart \& Lister, 2001; Hänfling et al., 2002; Murton \& Lautridou, 2003; Hoarau et al., 2007; Remerie et al., 2009). The location of the contact zone is similar to that hypothesized for the butterfly Maniola jurtina (Schmitt et al., 2005), which, however, expanded only from southern refugia (not from the British Isles). The contact zone in Schleswig-Holstein coincides with the main watershed between the Baltic and the North Sea. This may explain the affiliation of the samples from Lake Selent with those from the Baltic, and from the Plön lakes (which are only a few kilometres away) with those from British populations. One has to keep in mind the major postglacial alterations that occurred in this region. The formerly dry area of the North Sea was flooded due to rising sea level, which means that the present separation of the British Isles from the mainland is a relatively recent phenomenon (ca. 6,000 years). Likewise, the Macroplea populations that nowadays are separated by the North Sea may be derived from a more continuous ancestral population, in which genetic exchange across the North Sea in statu nascendi initially 
was possible, and which was gradually relocated to both sides of the widening marine habitat. During the last 1,000 years, the landscape in Central Europe, particularly Northern Germany, was greatly changed by man draining the lowlands, consolidating the land and regulating the rivers. This resulted in the isolation of Macroplea populations as the changes in the landscape altered the connectivity of its potential habitats (c.f. Verovnik et al., 2005).

\section{CONCLUSIONS}

Macroplea are as peculiar as expected on the basis of their natural history. They are the only fully aquatic leaf beetles and diverged about 50 million years ago from the amphibious sister genus Neohaemonia (Kölsch \& Pedersen, 2008). While it is not known when Macroplea became fully aquatic, the time span is shorter than the one other "typical" aquatic invertebrates had in which to evolve their life history traits (aquatic Coleoptera and Hemiptera: > 150 Mya; Grimaldi \& Engel, 2005), particularly a means of dispersal (Verberk et al., 2008a, b). Many of them show less population structure due to their habitual dispersal (Hughes et al., 2000; Wilcock et al., 2001; Miller et al., 2002; Brändle et al., 2005; Beebee, 2007; Zickovich \& Bohonak, 2007). The clear differentiation between Macroplea populations recorded is similar to that in terrestrial situations in which there are natural or man made barriers to dispersal (Takami et al., 2004; Vandewoestijne \& Baguette, 2004; Keyghobadi et al., 2005) or immobility (flightlessness) of the organisms (Brouat et al., 2003; Keller et al., 2004; Saitoh et al., 2007; Drees et al., 2008). It is a consequence of the prevailing hydrography and passive dispersal, with parallels in other freshwater invertebrates that have a poor dispersal ability (poor flyers, habitat specialists: Zera, 1981; Sweeney et al., 1987; Bilton, 1992; Hughes et al., 1999; Wishart \& Hughes, 2001; Verovnik et al., 2005; for a review of dispersal in these species, see Bilton et al., 2001).

This study revealed three areas that need closer study in the future. South-eastern Europe to corroborate the postulate of a south-eastern refugium based on the sample from Lake Balaton. Western Europe (particularly The Netherlands) to bridge the gap between the British Isles and the European mainland. And, last but not least, Northern Germany and Western Denmark (Jutland) in order to define the position of the contact zone. A parallel investigation of the sister species $M$. appendiculata might reveal how differences in the biology can influence the biogeography of a species.

ACKNOWLEDGEMENTS. We wish to thank all the people who contributed material for this study (Table 1). The support from conservation authorities in providing sampling permits and help with sampling in the field is gratefully acknowledged. We thank J. Sauer for fruitful discussions on various aspects of the AFLP method and two anonymous referees for their comments.

\section{REFERENCES}

AsKevold I.S. 1990: Reconstructed phylogeny and reclassification of the genera of Donaciinae (Coleoptera: Chrysomelidae). Quaest. Entomol. 26: 601-664.
Beebee T.J.C. 2007: Population structure and its implications for conservation of the great silver beetle Hydrophilus piceus in Britain. Freshw. Biol. 52: 2101-2111.

Bereczki J., Pecsenye K., Peregovits L. \& Varga Z. 2005: Pattern of genetic differentiation in the Maculinea alcon species group (Lepidoptera, Lycaenidae) in Central Europe. J. Zool. Syst. Evol. Res. 43: 157-165.

Besold J., Schmitt T., Tammaru T. \& Cassel-Lundhagen A. 2008: Strong genetic impoverishment from the centre of distribution in southern Europe to peripheral Baltic and isolated Scandinavian populations of the pearly heath butterfly. J. Biogeogr. 35: 2090-2101.

BILTON D.T. 1992: Genetic population structure of the postglacial relict diving beetle Hydroporus glabriusculus Aube (Coleoptera: Dytiscidae). Heredity 69: 503-511.

Bilton D.T., Freeland J.R. \& Okamura B. 2001: Dispersal in freshwater invertebrates. Annu. Rev. Ecol. Syst. 32: 159-181.

Bonin A., Ehrich D. \& MAnel S. 2007: Statistical analysis of amplified fragment length polymorphism data: a toolbox for molecular ecologists and evolutionists. Mol. Ecol. 16: 3737-3758.

BorowIEC L. 1984: Zoogeographical study on Donaciinae of the world (Coleoptera, Chrysomelidae). Pol. Pismo Entomol. 53: 433-518.

Böving A.G. 1910: Natural history of the larvae of Donaciinae. Int. Rev. Ges. Hydrobiol. Biol. (Suppl.) 3: 1-108.

Brändle M., Westermann I. \& Brandl R. 2005: Gene flow between populations of two invertebrates in springs. Freshw. Biol. 50: 1-9.

Brouat C., Sennedot F., Audiot P., Leblois R. \& Rasplus J.-Y. 2003: Fine-scale genetic structure of two carabid species with contrasted levels of habitat specialization. Mol. Ecol. 12: $1731-1745$.

Clausen P., Nolet B.A., Fox A.D. \& Klaassen M. 2002: Longdistance endozoochorous dispersal of submerged macrophyte seeds by migratory waterbirds in northern Europe - a critical review of possibilities and limitations. Acta Oecol. 23: 191-203.

Comes H.P. \& Kadereit J.W. 1998: The effect of quaternary climatic changes on plant distribution and evolution. Trends Plant Sci. 3: 432-438.

Cooper S.J.B., Ibrahim K.M. \& Hewitt G.M. 1995: Postglacial expansion and genome subdivision in the European grasshopper Chorthippus parallelus. Mol. Ecol. 4: 49-60.

Corander J., Waldmann P. \& Sillanpaa M.J. 2003: Bayesian analysis of genetic differentiation between populations. Genetics 163: 367-374.

Corander J., Waldmann P., Marttinen P. \& Sillanpaa M.J. 2004: BAPS 2: enhanced possibilities for the analysis of genetic population structure. Bioinformatics 20: 2363-2369.

DACCORDI M. \& Ruffo S. 1978: Sulla presenza del genere Macroplea Samouelle in Italia. Boll. Assoc. Rom. Entomol. 38: $56-65$.

DiCE L.R. 1945: Measures of the amount of ecological association between species. Ecology 26: 297-302.

Drees C., Matern A., Rasplus J.-Y., Terlutter H., Assmann T. \& Weber F. 2008: Microsatellites and allozymes as the genetic memory of habitat fragmentation and defragmentation in populations of the ground beetle Carabus auronitens (Col., Carabidae). J. Biogeogr. 35: 1937-1949.

EXCOFFIER L. \& RAY N. 2008: Surfing during population expansions promotes genetic revolutions and structuration. Trends Ecol. Evol. 23: 347-351. 
Excoffier L., Laval G. \& Schneider S. 2005: Arlequin ver. 3.0: An integrated software package for population genetics data analysis. Evol. Bioinform. Online 1: 47-50.

Felsenstein J. 2005: PHYLIP (Phylogeny Inference Package) version 3.6. Distributed by the author. Dept. of Genome Sciences, University of Washington, Seattle.

Figuerola J. \& GREen A.J. 2002: Dispersal of aquatic organisms by waterbirds: a review of past research and priorities for future studies. Freshw. Biol. 47: 483-494.

Freude H., Harde K.W. \& Lohse G.A. 1966: Die Käfer Mitteleuropas. Vol. 9. Goecke \& Evers, Krefeld, 299 pp.

GLiemeroth A.K. 1995: Palaeökologische Untersuchungen über die letzten 22000 Jahre in Europa: Vegetation, Biomasse und Einwanderungsgeschichte der wichtigsten Waldbäume. Gustav Fischer, Stuttgart, 252 pp.

Grapputo A., Boman S., Lindstrom L., Lyytinen A. \& Mappes J. 2005: The voyage of an invasive species across continents: genetic diversity of North American and European Colorado potato beetle populations. Mol. Ecol. 14: 4207-4219.

Green A.J., Figuerola J. \& SÁnchez M.I. 2002: Implications of waterbird ecology for the dispersal of aquatic organisms. Acta Oecol. 23: 177-189.

Green A.J. \& Figuerola J. 2005: Recent advances in the study of long-distance dispersal of aquatic invertebrates via birds. Divers. Distrib. 11: 149-156.

Green A.J. \& Sanchez M.I. 2006: Passive internal dispersal of insect larvae by migratory birds. Biol. Lett. 2: 55-57.

Grimaldi D. \& ENGEL M.S. 2005: Evolution of the Insects. Cambridge University Press, New York, 755 pp.

Habel J.C., Schmitt T. \& Müller P. 2005: The fourth paradigm pattern of post-glacial range expansion of European terrestrial species: the phylogeography of the marbled white butterfly (Satyrinae, Lepidoptera). J. Biogeogr. 32: 1489-1497.

Halliday R.B., Barton N.H. \& Hewitt G.M. 1983: Electrophoretic analysis of a chromosomal hybrid zone in the grasshopper Podisma pedestris. Biol. J. Linn. Soc. 19: 51-62.

Hänfling B., Hellemans B., Volckaert F.A.M. \& Carvalho G.R. 2002: Late glacial history of the cold-adapted freshwater fish Cottus gobio, revealed by microsatellites. Mol. Ecol. 11: $1717-1729$

Hangelbroek H.H., Ouborg N.J., Santamaría L. \& Schwenk K. 2002: Clonal diversity and structure within a population of the pondweed Potamogeton pectinatus foraged by Bewick's swan. Mol. Ecol. 11: 2137-2150.

HaRdy O.J. \& VeKEMANS X. 2002: SPAGeDi: a versatile computer program to analyse genetic structure at the individual or population levels. Mol. Ecol. Notes 2: 618-620.

Hartl D.L. \& Clark A.G. 2007: Principles of Population Genetics. 4th ed. Sinauer, Sunderland, MA, $652 \mathrm{pp}$.

Haubrich K. \& Schmitt T. 2007: Cryptic differentiation in alpine-endemic, high-altitude butterflies reveals down-slope glacial refugia. Mol. Ecol. 16: 3643-3658.

HewitT G.M. 1996: Some genetic consequences of ice ages, and their role in divergence and speciation. Biol. J. Linn. Soc. 58: 247-276.

HewitT G.M. 1999: Post-glacial re-colonization of European biota. Biol. J. Linn. Soc. 68: 87-112.

HewitT G.M. 2000: The genetic legacy of the Quaternary ice ages. Nature 405: 907-913.

HewitT G.M. 2004: Genetic consequences of climatic oscillations in the Quaternary. Phil. Trans. R. Soc. (B, Biol. Sci.) 359: 183-195.

Hoarau G., Veldsink H., Stam W.T. \& Olsen T. 2007: Glacial refugia and recolonization pathways in the brown seaweed Fucus serratus. Mol. Ecol. 16: 3606-1616.
HoInIC C. 1994: A review of the species of Macroplea Samouelle (Coleoptera: Chrysomelidae) in Romania. Trav. Mus. Hist. Nat. "Grigore Antipa" 34: 17-30.

Hollingsworth P.M. \& EnNos R.A. 2004: Neighbour joining trees, dominant markers and population genetic structure. Heredity 92: 490-498.

Holsinger K.E. \& LewIS P.O. 2003: Hickory: A package for Analysis of Population Genetic Data. University of Connecticut, Storrs, CT.

Hughes J.M., Mather P.B., Sheldon A.L. \& Allendorf F.W. 1999: Genetic structure of the stonefly, Yoraperla brevis, populations: the extent of gene flow among adjacent montane streams. Freshw. Biol. 41: 63-72.

Hughes J.M., Bunn S.E., Cleary C. \& Hurwood D.A. 2000: A hierarchical analysis of the genetic structure of an aquatic insect Bungona (Baetidae: Ephemeroptera). Heredity 85: 561-570.

Jansson R. \& Dynesius M. 2002: The fate of clades in a world of recurrent climate change: Milankovitch oscillations and evolution. Annu. Rev. Ecol. Syst. 33: 741-777.

Kazachkova N., Fahleson J. \& Meijer J. 2004: Establishment of the amplified fragment length polymorphism (AFLP) technique for genotyping of pollen beetle (Meligethes aeneus) - a noxious insect pest on oilseed rape (Brassica napus). Mol. Biol. Rep. 31: 37-42.

Keller I., Nentwig W. \& Largiader C.R. 2004: Recent habitat fragmentation due to roads can lead to significant genetic differentiation in an abundant flightless ground beetle. Mol. Ecol. 13: 2983-2994.

Keyghobadi N., Roland J. \& Strobeck C. 2005: Genetic differentiation and gene flow among populations of the alpine butterfly, Parnassius smintheus, vary with landscape connectivity. Mol. Ecol. 14: 1897-1909.

King R.A., Gornall R.J., Preston C.D. \& Cropf J.M. 2002: Population differentiation of Potamogeton pectinatus in the Baltic Sea with reference to waterfowl dispersal. Mol. Ecol. 11: 1947-1956.

Kölsch G. \& Pedersen B.V. 2008: Molecular phylogeny of reed beetles (Col., Chrysomelidae, Donaciinae): The signature of ecological specialization and geographical isolation. Mol. Phylogen. Evol. 48: 936-952.

Kölsch G., Biström O. \& Pedersen B.V. 2006: Species delimitation in the leaf beetle genus Macroplea (Coleoptera, Chrysomelidae) based on mitochondrial DNA, and phylogeographic considerations. Insect Syst. Evol. 37: 467-479.

Kosman E. \& Leonard K.J. 2005: Similarity coefficients for molecular markers in studies of genetic relationships between individuals for haploid, diploid, and polyploid species. Mol. Ecol. 14: 415-424.

Krauss S.L. 2000: Accurate gene diversity estimates from amplified fragment length polymorphism (AFLP) markers. Mol. Ecol. 9: 1241-1245.

LaYs P. 2002: Notes on the Donaciines (Coleoptera: Chrysomelidae: Donaciinae) (1-10). Bull. Soc. R. Belge Entomol. 138: 77-84.

Machlour-M'Rabet S., Mardulyn P. \& Pasteels J. 2008: Genetic differentiation among European samples of the arctic-alpine leaf beetle, Chrysomela lapponica. Entomol. Exp. Appl. 129: 181-188.

Mader E., van Vierssen W. \& Schwenk K. 1998: Clonal diversity in the submerged macrophyte Potamogeton pectinatus L. inferred from nuclear and cytoplasmic variation. Aquat. Bot. 62: 147-160.

ManN J.S. \& Crowson R.A. 1983: Observations on the internal anatomy and classification of Donaciinae (Col., Chrysomelidae). Entomol. Month. Mag. 119: 17-27. 
Margraf N., Verdon A., Rahier M. \& Naisbit R.E. 2007: Glacial survival and local adaptation in an alpine leaf beetle. Mol. Ecol. 16: 2333-2343.

Marklund O. \& SAndsten H. 2002: Reduction of benthic macroinvertebrates due to waterfowl foraging on submerged vegetation during autumn migration. Aquat. Ecol. 36: 541-547.

McMichael M. \& Prowell D.P. 1999: Differences in amplified fragment-length polymorphisms in fall armyworm (Lepidoptera: Noctuidae) host strains. Ann. Entomol. Soc. Am. 92: 175-181.

Medina R.F., Barbosa P., Christman M. \& Battisti A. 2006: Number of individuals and molecular markers to use in genetic differentiation studies. Mol. Ecol. Notes 6: 1010-1013.

Meudt H.M. \& Clarke A.C. 2007: Almost forgotten or latest practice? AFLP applications, analyses and advances. Trends Plant Sci. 12: 106-117.

Miller M.P., BlinN D.W. \& KeIM P. 2002: Correlations between observed dispersal capabilities and patterns of genetic differentation in populations of four aquatic insect species from the Arizona White Mountains U.S.A. Freshw. Biol. 47: 160-1673.

MoHR K.-H. 1985: Beiträge zur Insektenfauna der DDR: Coleoptera - Chrysomelidae: Donaciinae, Orsodacninae, Criocerinae, Clythrinae. Beitr. Entomol. 35: 219-262.

Monaghan M.T., SpaAK P., Robinson C.T. \& Ward J.V. 2001: Genetic differentiation of Baetis alpinus Pictet (Ephemeroptera: Baetidae) in fragmented alpine streams. Heredity 86: 395-403.

Mueller U.G. \& Wolfenbarger L.L. 1999: AFLP genotyping and fingerprinting. Trends Ecol. Evol. 14: 389-394.

Murton J.B. \& Lautridou J.-P. 2003: Recent advances in the understanding of Quaternary periglacial features of the English Channel coastlands. J. Quat. Sci. 18: 301-307.

Ner M. 1987: Molecular Evolutionary Genetics. Columbia University Press, New York, 512 pp.

Nyвом H. 2004: Comparison of different nuclear DNA markers for estimating intraspecific genetic diversity in plants. Mol. Ecol. 13: 1143-1155.

PARSONS Y.M. \& SHAW K.L. 2001: Species boundaries and genetic diversity among Hawaiian crickets of the genus Laupala identified using amplified fragment length polymorphism. Mol. Ecol. 10: 1765-1772.

Paupy C., Orsoni A., Mousson L. \& Huber K. 2004: Comparisons of amplified fragment length polymorphism (AFLP), microsatellite, and isoenzyme markers: population genetics of Aedes aegypti (Diptera: Culicidae) from Phnom Penh (Cambodia). J. Med. Entomol. 41: 664-671.

Peterson M.A. \& Denno R.F. 1998: The influence of dispersal and diet breadth on patterns of genetic isolation by distance in phytophagous insects. Am. Nat. 152: 428-446.

Picone S., Alvisi F., Dinelli E., Morigi C., Negri A., Ravaiol M. \& VACCARO C. 2008: New insights on late quaternary palaeogeographic setting in the northern Adriatic sea (Italy). J. Quat. Sci. 23: 489-501.

Pompanon F., Bonin A., Bellemain E. \& Taberlet P. 2005 : Genotyping errors: causes, consequences and solutions. Nat. Rev. Genet. 6: 847-846.

Previšić A., Walton C., Kučinić M., Mitrikeski P.T. \& Kerovec M. 2009: Pleistocene divergence of Dinaric Drusus endemics (Trichoptera, Limnephilidae) in multiple microrefugia within the Balkan Peninsula. Mol. Ecol. 18: 634-647.

Remerie T., Vierstraete A., Weekers P.H.H., Vanfleteren J.R. \& VAnReusel A. 2009: Phylogeography of an estuarine mysid, Neomysis integer (Crustacea, Mysida), along the north-east Atlantic coasts. J. Biogeogr. 36: 39-54.

Rogers J.P. \& Korschgen L.J. 1966: Foods of lesser scaups on breeding, migration and wintering areas. J. Wildl. Manag. 30: 258-264.

RÜger A., Prentice C. \& Owen M. 1986: Results of the IWRB International Waterfowl Census 1967-1983. Population Estimates and Trends in Selected Species of Ducks, Swans and Coot from the January Counts in the Western Palearctic. IWRB, Slimbridge, 118 pp.

Saitoh S., Miyai S.I. \& KataKura H. 2007: Geographical variation and diversification in the flightless leaf beetles of the Chrysolina angusticollis species complex (Chrysomelidae, Coleoptera) in northern Japan. Biol. J. Linn. Soc. 93: 557-578.

Salvato P., Battisti A., Concato S., Masutti L., Patarnello T. \& ZANE L. 2002: Genetic differentiation in the winter pine processionary moth (Thaumetopoea pityocampa-wilkinsoni complex), inferred by AFLP and mitochondrial markers. Mol. Ecol. 11: 2435-2444.

Sauer J. \& Hausdorf B. 2009: Sexual selection is involved in speciation in a land snail radiation on Crete. Evolution 63: 2535-2546.

Schmitt T. 2007: Molecular biogeography of Europe: Pleistocene cycles and postglacial trends. Front. Zool. 4: 11.

Schmitt T. \& Haubrich K. 2008: The genetic structure of the mountain forest butterfly Erebia euryale unravels the late Pleistocene and postglacial history of the mountain coniferous forest biome in Europe. Mol. Ecol. 17: 2194-2207.

Schmitt T. \& SeITz A. 2001: Intraspecific allozymatic differentiation reveals the glacial refugia and the postglacial expansions of European Erebia medusa (Lepidoptera: Nymphalidae). Biol. J. Linn. Soc. 74: 429-458.

Schmitt T., Röber S. \& Seitz A. 2005: Is the last glaciation the only relevant event for the present genetic population structure of the meadow brown butterfly Maniola jurtina (Lepidoptera: Nymphalidae)? Biol. J. Linn. Soc. 85: 419-431.

Schmitt T., Habel J.C., Zimmermann M. \& Müller P. 2006: Genetic differentiation of the marbled white butterfly, Melanargia galathea, accounts for glacial distribution patterns and postglacial range expansion in southeastern Europe. Mol. Ecol. 15: 1889-1901.

Sinclair W.T., Morman J.D. \& EnNos R.A. 1998: Multiple origins for Scots pine (Pinus sylvestris L.) in Scotland: evidence from mitochondrial DNA variation. Heredity 80: 233-240.

SLATKIN M. 1993: Isolation by distance in equilibrium and nonequilibrium populations. Evolution 47: 264-279.

SoKAL R.R. \& Michener C.D. 1958: A statistical method for evaluating systematic relationships. Univ. Kans. Sci. Bull. 38: 1409-1438.

SoKolov E.P. 2000: An improved method for DNA isolation from mucopolysaccharide-rich molluscan tissue. J. Mollusc. Stud. 66: 573-575.

StewArt J.R. \& Lister A.M. 2001: Cryptic northern refugia and the origins of the modern biota. Trends Ecol. Evol. 16: 608-613.

Sweeney B.W., Funk D.H. \& Vannote R.L. 1987: Genetic variation in stream mayfly (Insecta: Ephemeroptera) populations of Eastern North America. Ann. Entomol. Soc. Am. 80: 600-612.

SzÉKESSY V. 1941: Haemonia mutica balatonica nov. subsp. (Coleopt., Chrysom.). Fragm. Faun. Hung. 4: 21-22.

Taberlet P., Fumagalli L., Wust-Saucy A.-G. \& Cosson J.-F. 1998: Comparative phylogeography and postglacial colonization routes in Europe. Mol. Ecol. 7: 453-464. 
Takami Y., Koshio C., IshiI M., Fuji H., Hidaka T. \& Shimizu I. 2004: Genetic diversity and structure of urban populations of Pieris butterflies assessed using amplified fragment length polymorphism. Mol. Ecol. 13: 245-258.

Tamura K., Dudley J., Nei M. \& Kumar S. 2007: MEGA4: Molecular Evolutionary Genetics Analysis (MEGA) software version 4.0. Mol. Biol. Evol. 24: 1596-1599.

Tan Y.-D., Wan C., Zhu Y., Lu C., Xiang Z. \& Deng H.-W. 2001: An amplified fragment length polymorphism map of the silkworm. Genetics 157: 1277-1284.

Timmermans M.J.T.N., Ellers J., Marien J., Verhoef S.C., Ferwerda E.B. \& van StraAlen N.M. 2005: Genetic structure in Orchesella cincta (Collembola): strong subdivision of European populations inferred from mtDNA and AFLP markers. Mol. Ecol. 14: 2017-2024.

VAN DeR WurfF A.W.G., IsaAks J.A., ERnsting G. \& VAN StraAlen N.M. 2003: Population substructures in the soil invertebrate Orchesella cincta, as revealed by microsatellite and TE-AFLP markers. Mol. Ecol. 12: 1349-1359.

Vandewoestijne S. \& Baguette M. 2004: Genetic population structure of the vulnerable bog fritillary butterfly. Hereditas 141: 199-206.

VeKEMANS X. 2002: AFLP-SURV Version 1.0. Distributed by the author. Laboratoire de Génétique et Ecologie Végétale, Université Libre de Bruxelles, Belgium.

Verberk W.C.E.P., Siepel H. \& EsselinK H. 2008a: Applying life-history strategies for freshwater macroinvertebrates to lentic waters. Freshw. Biol. 53: 1739-1753.

Verberk W.C.E.P., Siepel H. \& Esselink H. 2008b: Life-history strategies in freshwater macroinvertebrates. Freshw. Biol. 53: $1722-1738$.
Verovinik R., Sket B. \& Trontelu P. 2005: The colonization of Europe by the freshwater crustacean Asellus aquaticus (Crustacea: Isopoda) proceeded from ancient refugia and was directed by habitat connectivity. Mol. Ecol. 14: 4355-4369.

Vos P., Hogers R., Bleeker M., Reijans M., van de Lee T., Hornes M., Frijters A., Рot J., Peleman J., Kuiper M. \& ZABEAU M. 1995: AFLP: a new technique for DNA fingerprinting. Nucl. Acids Res. 23: 4407-4414.

Wahlberg N. \& SAccheri I. 2007: The effects of Pleistocene glaciations on the phylogeography of Melitaea cinxia (Lepidoptera: Nymphalidae). Eur. J. Entomol. 104: 675-684.

WeSENBERG-Lund C. 1943: Biologie der Süsswasserinsekten. Springer, Berlin, $682 \mathrm{pp}$.

Wilcock H.R., Hildrew A.G. \& Nichols R.A. 2001: Genetic differentiation of a European caddisfly: past and present gen flow among fragmented larval habitats. Mol. Ecol. 10: $1821-1834$.

Wishart M.J. \& Hughes J.M. 2001: Exploring patterns of population subdivision in the net-winged midge, Elporia barnardi (Diptera: Blephariceridae), in mountain streams of the southwestern Cape, South Africa. Freshw. Biol. 46: 479-490.

ZERA A. 1981: Genetic structure of two species of waterstriders (Gerridae: Hemiptera) with differing degrees of winglessness. Evolution 35: 218-225.

Zickovich J.M. \& BoHONAK A.J. 2007: Dispersal ability and genetic structure in aquatic invertebrates: a comparative study in southern California streams and reservoirs. Freshw. Biol. 52: 1982-1996.

Received July 22, 2009; revised and accepted September 24, 2009 